\title{
In Vivo Antipyretic, Analgesic, and Anti-inflammatory Activities of the Brown Alga Ecklonia cava Extracts in Mice
}

\author{
Ji-Young Kang, ${ }^{1}$ Jae-Suk Choi ${ }^{2}$, Nam Gyu Park' ${ }^{1}$ Dong-Hyun Ahn ${ }^{3}$ and Yong-Ki Hong ${ }^{1 *}$ \\ ${ }^{1}$ Department of Biotechnology, Pukyong National University, Busan 608-737, Korea \\ ${ }^{2}$ RIS Center, Silla University, Busan 617-736, Korea \\ ${ }^{3}$ Department of Food Science and Technology, Pukyong National University, Busan 608-737, Korea
}

\begin{abstract}
Dichloromethane, ethanol, and boiling water extracts of the brown alga Ecklonia cava were examined in vivo for their antipyretic, analgesic, and anti-inflammatory activities in mice. These activities were evaluated by yeast-induced pyrexia, tail-flick test, and phorbol myristate acetate-induced inflammation (edema, erythema, and blood flow). Ethanol extract of $E$. cava ( $0.4 \mathrm{mg} / \mathrm{ear}) \mathrm{inhib}-$ ited the inflammatory symptoms of mouse ear edema, erythema, and blood flow by $82.6 \%, 69.0 \%$, and $65.4 \%$, respectively. This extract also demonstrated potent analgesic activity. No acute toxicity was observed after p.o. administration of each extract (5 g/ $\mathrm{kg} \mathrm{bw})$. These in vivo data are in agreement with the claims of the health care industry and indigenous medicine that $E$. cava is an effective remedy for inflammation-related symptoms.
\end{abstract}

Key words: Ecklonia cava, Analgesic, Anti-inflammation, Antipyretic, Phaeophyta, In vivo assay

\section{Introduction}

The brown seaweed Ecklonia cava Kjellman is abundant in the subtidal region of Jeju Island and the southern coast of Korea. It is used as abalone feed (Kang, 1968) and in treatments of hemorrhoids and gastroenteritis, as well as insecticide, as recorded in the Oriental medical textbook Donguibogam published in 1613 (Donguibogam Committee, 1999). E. cava is also used as a source for an immune-booster, which has been claimed to contain antitumor, anticoagulant, and antithrombin polysaccharides (Koyanagi et al., 2003). The seaweed contains marine polyphenols known as phlorotannins (Li et al., 2009), which are found only in brown algae, synthesized via an acetate-melonate pathway and formed by the polymerization of phloroglucinol (1,3,5-trihydroxybenzene) (Ragan and Glombitza, 1986). Recently, accumulating evidence suggests that $E$. cava exhibits matrix metalloproteinase inhibitory activity (Kim et al., 2006), bactericidal activity (Jin et al., 1997), protease inhibition (Ahn et al., 2004), and effects on osteoarthritis (Shin et al., 2006), asthma (Kim et al., 2008), and melanogenesis (Heo et al., 2009). Numerous studies have examined the antioxidant properties of extracts (Jung et al., 2009) or chemical components (Kang et al., 2004; Heo et al., 2009; Li et al., 2009). E. cava polysaccharide also showed anti-inflammatory activity mediated by inhibition of NO and prostaglandin $\mathrm{E}_{2}$ production (Jung et al., 2009; Kang et al., 2011). The underlying mechanism may involve repression of inflammation by antioxidant substances (Garrett and Grisham, 2005). Thus, to evaluate the anti-inflammatory activities of $E$. cava, we assayed in vivo the anti-inflammatory activities of dichloromethane, ethanol, and boiling water extracts against hyperpyrexia, algesthesia, edema, erythema, and local blood flow in mice.
Open Access http://dx.doi.org/10.5657/FAS.2012.0073

This is an Open Access article distributed under the terms of the Creative Commons Attribution Non-Commercial License (http://creativecommons. org/licenses/by-nc/3.0/) which permits unrestricted non-commercial use, distribution, and reproduction in any medium, provided the original work is properly cited. pISSN: 2234-1749 eISSN: 2234-1757
Received 22 September 2011; Revised 7 February 2012; Accepted 8 February 2012

*Corresponding Author

E-mail: ykhong@pknu.ac.kr 


\section{Materials and Methods}

\section{Seaweed materials}

Thalli of the brown seaweed E. cava were collected from the coast of Kijang, Korea, from August 2008 to 2010. The scientific name of the seaweed described in the Donguibogam was identified from its common or local names (Suh, 1997). A voucher specimen is deposited in our laboratory (Y. K. Hong). For convenience, the seaweed tissue was completely dried for 1 week at room temperature and then ground to powder for 5 min by a coffee grinder. The powder was stored at $-20^{\circ} \mathrm{C}$ until use. Dichloromethane or ethanol (1 L) was used to extract 20 $\mathrm{g}$ of the seaweed powder by shaking at room temperature for $1 \mathrm{~h}$. For the water-soluble fraction, distilled water was boiled for $1 \mathrm{~h}$. The crude extract was evaporated under vacuum and dried under nitrogen. To remove salt from extracts, extractions were repeated several times (from the previous solvent-soluble fraction) until the amount of salt was visibly negligible.

\section{Animals}

BALB/c mice (8-10 weeks old; 20-25 g body weight) were used to assay various anti-inflammatory activities. The animals were kept at room temperature $\left(24 \pm 1^{\circ} \mathrm{C}\right)$ on a $12 \mathrm{~h}$ light/dark cycle with free access to food and water. Animal experiments were performed in accordance with the U. S. NIH Guidelines for the Care and Use of Laboratory Animals.

\section{Antipyretic activity}

A brewer's yeast-induced pyrexia mouse model was used to determine the antipyretic activity (Teotino et al., 1963). When the rectal temperature peaked after $24 \mathrm{~h}$, extracts $(4 \mathrm{~g})$ in 10 $\mathrm{mL}$ of $5 \%$ Tween- 80 or $10 \mathrm{~mL}$ of $5 \%$ Tween- 80 (control) per $\mathrm{kg}$ body weight were administered orally, and the rectal temperature $\left({ }^{\circ} \mathrm{C}\right)$ was recorded after an additional 45 min using an electric thermometer connected to a probe, inserted $2 \mathrm{~cm}$ into the rectum. Relative temperature suppression (\%) is expressed as [(value of the control - value of the extract)/value of the control] $\times 100$. Acetyl salicylic acid (aspirin, $150 \mathrm{mg} / \mathrm{kg}$, p.o.) was used as a standard.

\section{Analgesic activity}

In the tail-flick test (Gray et al., 1970), extracts (1.5 g/10 $\mathrm{mL}$ of $5 \%$ Tween- $80 / \mathrm{kg}$ body weight) or control was administered i.p. to mice, and tail-flick latency time(s) was measured 1 $\mathrm{h}$ later using a tail-flick unit (Ugo Basile, Varese, Italy). Relative latency $(\%)$ was expressed as [(value of the extract - value of the control)/value of the control] $\times 100$. Acetyl salicylic acid $(150 \mathrm{mg} / \mathrm{kg}$, p.o. $)$ in the same volume of vehicle was used as a standard.

\section{Anti-inflammatory activity}

Stock solutions of the extracts were prepared by adding ethanol $(1 \mathrm{~mL})$ to dried seaweed extracts $(40 \mathrm{mg})$. Phorbol 12-myristate 13-acetate (PMA; Sigma, St. Louis, MO, USA) in acetone $\left(0.2 \mu \mathrm{g} 10 \mu \mathrm{L}^{-1}\right.$ ear $\left.^{-1}\right)$ was combined with the seaweed extracts in ethanol $\left(0.4 \mathrm{mg} 10 \mu \mathrm{L}^{-1}\right.$ ear $\left.^{-1}\right)$ and topically applied to the whole inner side of the mouse's ear. Ear edema was measured after $10 \mathrm{~h}$ using a spring-loaded micrometer (Mitutoyo Corp., Tokyo, Japan) (Griswold et al., 1998). Ear erythema was determined at $10 \mathrm{~h}$ by digital photography, adjusted to balance white, and Photoshop 7.0 (Adobe, San Jose, CA, USA) was used to measure the magenta value (Khan et al., 2008). To confirm the anti-inflammatory activity of the seaweed, local blood flow in the mouse ear was measured by laser speckle flowgraphy (Inflameter LFG-1; SoftCare, Fukuoka, Japan) (Lee et al., 2003). Edema (AU), erythema (AU), and blood flow (AU) values were calculated as $\left(I_{10}-I_{0}\right) / I_{0}$, where $I_{10}$ is the measurement $10 \mathrm{~h}$ after PMA application and $I_{0}$ is the measurement at $0 \mathrm{~h}$. The relative inhibition rate (\%) was expressed as [(value of the control - value of the extract $) /$ value of the control] $\times 100$. Indomethacin $(0.3$ mg $10 \mu \mathrm{L}$-ethanol ${ }^{-1}$ ear $^{-1}$ ) was used as a standard.

\section{Acute toxicity test}

Mice were fasted for $6 \mathrm{~h}$, with water provided ad libitum. Extracts $(5 \mathrm{~g} / 10 \mathrm{~mL}$ of $5 \%$ Tween- $80 / \mathrm{kg}$ bw) were administered orally to mice ( $n=5$, each). The animals were then observed for any abnormal behavior for $3 \mathrm{~h}$, and mortality was noted for up to 2 weeks. A group of animals treated with Tween- 80 served as the control.

\section{Statistical analysis}

All animal experiments were performed with at least seven mice per group, and the highest and lowest values were discarded. Data are presented as means $\pm \mathrm{SE}$. The significance of the results was calculated using Student's $t$-test, and differences were deemed statistically significant at $P<0.01$.

\section{Results and Discussion}

When preparing traditional medicines and health care foods, the materials are commonly boiled in water or soaked in beverage alcohol. To undertake more detailed investigations of the active substances in E. cava, we prepared boiling water-, alcohol-, and dichloromethane-soluble seaweed extracts. Brownish extracts of boiling water (yield, 15.6\%), ethanol (yield, 1.7\%), and dichloromethane (yield, 0.3\%) were obtained. The antipyretic activity was evaluated by measuring changes in rectal temperature. When the mice were injected with brewer's yeast, the rectal temperature peaked at $39.19 \pm$ $0.07^{\circ} \mathrm{C}$, which was above the normal $38.45 \pm 0.06^{\circ} \mathrm{C}$, at $24 \mathrm{~h}$. 
Oral administration of the extracts marginally lowered rectal temperatures in hyperthermic mice (Table 1). Tail-flick behavior was used to evaluate extract analgesic activity. As controls, mice injected with 5\% Tween 80 responded by tail flicking in $3.08 \pm 0.04$ s. I.p. injection of ethanol extract increased the latency by $3.83 \pm 0.22 \mathrm{~s}$. The conditions for inducing mouse ear edema, erythema, and local blood flow by topical application of PMA were optimized by applying $0.2 \mu \mathrm{g}$ PMA and measuring ear thickness after $10 \mathrm{~h}$. PMA mixed with the ethanol extract $(0.4 \mathrm{mg} /$ ear $)$ demonstrated an edema value of $0.15 \pm$ 0.05 AU, representing $82.6 \%$ inhibition compared to the PMA control (Table 1). Indomethacin $(0.3 \mathrm{mg} / \mathrm{ear})$, a standard antiinflammatory drug, showed $0.14 \pm 0.01 \mathrm{AU}$, with $83.7 \%$ inhibition when applied with PMA to the mouse ear. The observed erythema value with $0.2 \mu \mathrm{g}$ PMA was $0.58 \pm 0.01$ AU. PMA plus ethanol extract $(0.4 \mathrm{mg} /$ ear $)$ demonstrated an erythema value of $0.18 \pm 0.04 \mathrm{AU}$, with $69.0 \%$ inhibition. Indomethacin showed $0.22 \pm 0.08 \mathrm{AU}$, with $62.1 \%$ inhibition. To confirm the inhibition of edema and erythema, we measured local blood flow by laser speckle flowgraphy. The blood flow value for $0.2 \mu \mathrm{g}$ PMA was $0.081 \pm 0.005 \mathrm{AU}$, and that of the PMA plus ethanol extract was $0.028 \pm 0.005$ AU. E. cava ethanol extract (i.e., likely nonpolar compounds) showed potent in vivo anti-inflammatory activities $(P<0.001)$ in mice. We evaluated acute toxicity of the extracts, even though the seaweed is used as feed and herbal medicine in Korea. During the 2-week observation period, no death occurred in any group $(n=5)$ administered $5 \mathrm{~g} / \mathrm{kg}$ bw. Most of the mice administered extracts reacted immediately by jumping, sleeping, scaling, and writhing for 5-10 min, and returned to normal behavior after $1.5 \mathrm{~h}$.

In this study, we demonstrated that E. cava ethanol extract inhibited PMA-induced inflammation. Topical application of PMA induces a long-lasting inflammatory response, resulting from protein kinase $\mathrm{C}(\mathrm{PKC})$ activation associated with a transient increase in prostanoid production and marked cellular influx (Nishizuka, 1989). This high prostaglandin level is likely due to cyclooxygenase (COX) induction (Müller-Deck- er et al., 1995). Treatment of mouse skin with a PKC activator, such as PMA, induces the formation of free radicals in vivo (Wei and Frenkel, 1992). E. cava has intracellular radical scavenging activity in BV2 microglia, suggesting a possible mechanism for the inhibitory effect of E. cava on NF-jB activation (Jung et al., 2009). Therefore, the potential inhibition of reactive oxygen species generation by $E$. cava is consistent with the inhibition of NF-jB-dependent cytokines and inducible nitric oxide synthase and COX-2 expression, and thus reduced inflammation. The tail-flick response is believed to be a spinally mediated reflex (Chapman et al., 1985). Several inflammatory mediators produce algesthesia by peripheral and spinal sensory fiber sensitization through protein kinase activation, including PKC (Scholz and Woolf, 2002). Algesthesia is associated with the formation of edema and erythema by PMA treatment (Tsuchiya et al., 2005), and thus the main active constituents in E. cava ethanol extract may inhibit the pathway that mediates the pain, edema, and erythema associated with inflammation. An herbal medicine is considered toxic if the $\mathrm{LD}_{50}$ is lower than $5 \mathrm{~g} / \mathrm{kg}$ body weight (World Health Organization, 1992). Thus, the E. cava extracts are not toxic and can be safely used by humans at moderate doses, since no mortality at $5 \mathrm{~g} / \mathrm{kg}$ bw was recorded. In conclusion, our data indicate that ethanol extract of the brown seaweed E. cava has anti-inflammatory and analgesic activities in vivo, with no serious toxic effect at moderate doses. These findings reinforce the claims of the health care industry and indigenous medicine that $E$. cava can be used as a remedy for inflammation-related symptoms.

\section{Acknowledgments}

This research was supported by a grant from the Busan Sea mustard Sea tangle Regional Strategic Food Industry Promotion Agency funded by MIFAFF, Korea. We thank the Brain Busan 21 Program for graduate support (JYK).

Table 1. Effect of Ecklonia cava extracts on antipyretic, analgesic, and anti-inflammatory activities against edema, erythema, and local blood flow, respectively, in mice

\begin{tabular}{|c|c|c|c|c|c|}
\hline & $\begin{array}{c}\text { Temperature } \\
\text { (antipyrexia \%) }\end{array}$ & $\begin{array}{c}\text { Tail flick } \\
\text { (latency \%) }\end{array}$ & $\begin{array}{c}\text { Edema } \\
\text { (inhibition \%) }\end{array}$ & $\begin{array}{c}\text { Erythema } \\
\text { (inhibition \%) }\end{array}$ & $\begin{array}{c}\text { Blood flow } \\
\text { (inhibition \%) }\end{array}$ \\
\hline Control & $\begin{array}{c}36.92 \pm 0.10 \\
(-)\end{array}$ & $\begin{array}{c}3.08 \pm 0.04 \\
(-)\end{array}$ & $\begin{array}{c}0.86 \pm 0.03 \\
(-)\end{array}$ & $\begin{array}{c}0.58 \pm 0.01 \\
(-)\end{array}$ & $\begin{array}{c}0.081 \pm 0.005 \\
(-)\end{array}$ \\
\hline Boiling water extract & $\begin{array}{c}36.42 \pm 0.23 \\
(1.4)\end{array}$ & $\begin{array}{c}3.19 \pm 0.23 \\
(3.6)\end{array}$ & $\begin{array}{c}0.74 \pm 0.04 \\
(14.0)\end{array}$ & $\begin{array}{l}0.37 \pm 0.02^{* *} \\
(36.2)\end{array}$ & $\begin{array}{c}0.073 \pm 0.015 \\
(9.9)\end{array}$ \\
\hline EtOH extract & $\begin{array}{c}36.88 \pm 0.14 \\
(0.1)\end{array}$ & $\begin{array}{l}3.83 \pm 0.22^{* *} \\
(24.4)\end{array}$ & $\begin{array}{c}0.15 \pm 0.05^{* *} \\
(82.6)\end{array}$ & $\begin{array}{c}0.18 \pm 0.04^{* *} \\
(69.0)\end{array}$ & $\begin{array}{c}0.028 \pm 0.011^{* *} \\
(65.4)\end{array}$ \\
\hline $\mathrm{CH}_{2} \mathrm{Cl}_{2}$ extract & $\begin{array}{c}36.46 \pm 0.14 \\
(1.2)\end{array}$ & $\begin{array}{c}3.49 \pm 0.15 \\
(13.3)\end{array}$ & $\begin{array}{l}0.81 \pm 0.03 \\
\quad(5.8)\end{array}$ & $\begin{array}{c}0.58 \pm 0.06 \\
(0)\end{array}$ & $\begin{array}{c}0.073 \pm 0.005 \\
(9.9)\end{array}$ \\
\hline Acetyl salicylic acid & $\begin{array}{c}35.38 \pm 0.58^{*} \\
(4.2)\end{array}$ & $\begin{array}{c}4.40 \pm 0.30^{* *} \\
(42.8)\end{array}$ & $(-)$ & $(-)$ & $(-)$ \\
\hline Indomethacin & $(-)$ & $\begin{array}{l}- \\
(-)\end{array}$ & $\begin{array}{l}0.14 \pm 0.01^{* *} \\
(83.7)\end{array}$ & $\begin{array}{l}0.22 \pm 0.08^{* * *} \\
(62.1)\end{array}$ & $\begin{array}{c}0.024 \pm 0.016^{* *} \\
(70.4)\end{array}$ \\
\hline
\end{tabular}

Each value represents the mean $\pm \mathrm{SE} ; n \geq 5$. -, no administration of drug. ${ }^{*} P<0.01$ as compared with control. ${ }^{* *} P<0.001$ as compared with control. 


\section{References}

Ahn MJ, Yoon KD, Min SY, Lee JS, Kim JH, Kim TG, Kim SH, Kim NG, Huh H and Kim J. 2004. Inhibition of HIV-1 reverse transcriptase and protease by phlorotannins from the brown alga Ecklonia cava. Biol Pharm Bull 27, 544-547.

Chapman CR, Casey KL, Dubner R, Foley KM, Gracely RH and Reading AE. 1985. Pain measurement: an overview. Pain 22, 1-31.

Donguibogam Committee. 1999. Translated Donguibogam. Bubinmunwha Press, Seoul, KR.

Garrett RH and Grisham CM. 2005. Biochemistry. 3rd ed. Thomson Learning, Inc., Belmont, CA, US.

Gray WD, Osterberg AC and Scuto TJ. 1970. Measurement of the analgesic efficacy and potency of pentazocine by the D'Amour and Smith method. J Pharmacol Exp Ther 172, 154-162.

Griswold DE, Martin LD, Badger AM, Breton J and Chabot-Fletcher M. 1998. Evaluation of the cutaneous anti-inflammatory activity of azaspiranes. Inflamm Res 47, 56-61.

Heo SJ, Ko SC, Cha SH, Kang DH, Park HS, Choi YU, Kim D, Jung WK and Jeon YJ. 2009. Effect of phlorotannins isolated from Ecklonia cava on melanogenesis and their protective effect against photo-oxidative stress induced by UV-B radiation. Toxicol in Vitro 23, 1123-1130.

Jin HJ, Kim JH, Sohn CH, DeWreede RE, Choi TJ, Towers GHN, Hudson JB and Hong YK. 1997. Inhibition of Taq DNA polymerase by seaweed extracts from British Columbia, Canada and Korea. J Appl Phycol 9, 383-388.

Jung WK, Ahn YW, Lee SH, Choi YH, Kim SK, Yea SS, Choi I, Park SG, Seo SK, Lee SW and Choi IW. 2009. Ecklonia cava ethanolic extracts inhibit lipopolysaccharide-induced cyclooxygenase-2 and inducible nitric oxide synthase expression in BV2 microglia via the MAP kinase and NF-kB pathways. Food Chem Toxicol 47, 410-417.

Kang HS, Chung HY, Kim JY, Son BW, Jung HA and Choi JS. 2004. Inhibitory phlorotannins from the edible brown alga Ecklonia stolonifera on total reactive oxygen species (ROS) generation. Arch Pharm Res 27, 194-198.

Kang JW. 1968. Illustrated Encyclopedia of Fauna and Flora of Korea. Vol. 8. Marine Algae. Samhwa Press, Seoul, KR.

Kang SM, Kim KN, Lee SH, Ahn G, Cha SH, Kim AD, Yang XD, Kang MC and Jeon YJ. 2011. Anti-inflammatory activity of polysaccharide purified from AMG-assistant extract of Ecklonia cava in LPSstimulated RAW 264.7 macrophages. Carbohydr Polym 85, 80-85.

Khan MNA, Lee MC, Kang JY, Park NG, Fujita H and Hong YK. 2008. Effects of the brown seaweed Undaria pinnatifida on erythematous inflammation assessed using digital photo analysis. Phytother Res
$22,634-639$

Kim MM, Ta QV, Mendis E, Rajapakse N, Jung WK, Byun HG, Jeon YJ and Kim SK. 2006. Phlorotannins in Ecklonia cava extract inhibit matrix metalloproteinase activity. Life Sci 79, 1436-1443.

Kim SK, Lee DY, Jung WK, Kim JH, Choi I, Park SG, Seo SK, Lee SW, Lee CM, Yea SS, Choi YH and Choi IW. 2008. Effects of Ecklonia cava ethanol extracts on airway hyperresponsiveness and inflammation in a murine asthma model: role of suppressor of cytokine signaling. Biomed Pharmacother 62, 289-296.

Koyanagi S, Tanigawa N, Nakagawa H, Soeda S and Shimeno H. 2003. Oversulfation of fucoidan enhances its anti-angiogenic and antitumor activities. Biochem Pharmacol 65, 173-179.

Lee MC, Konishi N and Fujii H. 2003. Blood flow analyses of skin tissue under the sacrum using laser speckle flowgraphy. Opt Rev 10, 562-566.

Li Y, Qian ZJ, Ryu B, Lee SH, Kim MM and Kim SK. 2009. Chemical components and its antioxidant properties in vitro: an edible marine brown alga Ecklonia cava. Bioorg Med Chem 17, 1963-1973.

Müller-Decker K, Scholz K, Marks E and Fürstenberger G. 1995. Differential expression of prostaglandin $\mathrm{H}$ synthase isozymes during multistage carcinogenesis in mouse epidermis. Mol Carcinog 12, 31-41.

Nishizuka Y. 1989. Studies and prospectives of the protein kinase C family for cellular regulation. Cancer 63, 1892-1903.

Ragan MA and Glombitza K. 1986. Phlorotannins, brown algal polyphenols. Prog Phycol Res 4, 177-241.

Scholz J and Woolf CJ. 2002. Can we conquer pain? Nat Neurosci 5 Suppl, 1062-1067.

Shin HC, Hwang HJ, Kang KJ and Lee BH. 2006. An antioxidative and antiinflammatory agent for potential treatment of osteoarthritis from Ecklonia cava. Arch Pharm Res 29, 165-171.

Suh KT. 1997. Classification of herbs in decoction part of Donguibogam. Ph.D. Dissertation, Kyungsung University, Busan, KR.

Teotino UM, Friz LP, Gandini A and Dellabella D. 1963. Thio derivatives of 2,3-dihydro-4H-1,3-benzoazin-4-one: synthesis and pharmacological properties. J Med Chem 6, 248-250.

Tsuchiya M, Sakakibara A and Yamamoto M. 2005. A tachykinin NK1 receptor antagonist attenuates the 4-beta-phorbol-12-myristate13-acetate-induced nociceptive behaviour in the rat. Eur J Pharmacol 507, 29-34.

Wei H and Frenkel K. 1992. Suppression of tumor promoter-induced oxidative events and DNA damage in vivo by sarcophytol A: a possible mechanism of antipromotion. Cancer Res 52, 2298-2303.

World Health Organization. 1992. Research Guidelines for Evaluating the Safety and Efficacy of Herbal Medicine. Regional Office for Western Pacific, Manila, PH. 